\title{
Late Paleozoic polyphased tectonics in the SW Belledonne massif (external crystalline massifs, French Alps)
}

\author{
Alain Fernandez ${ }^{a}$, Stéphane Guillot ${ }^{b}, *$, René-Pierre Ménot ${ }^{c}$, Patrick Ledru ${ }^{\mathrm{d}}$ \\ ${ }^{\mathrm{a}}$ Geology Institute, University of Bern, Balterstrasse 1, 3014 Bern, Switzerland \\ ${ }^{\mathrm{b}}$ Laboratoire de dynamique de la lithosphère, CNRS UMR 5570, UCB-Lyon and ENS-Lyon, 27, boulevard du 11 Novembre, 69622 Villeurbanne, France \\ ${ }^{\mathrm{c}}$ Département de géologie-pétrologie, CNRS, UMR 6524, université Jean Monnet, 23, rue Dr Paul Michelon, 42023 Saint-Etienne cedex 2, France \\ ${ }^{\mathrm{d}} B R G M, B P$ 6009, 45060 Orléans Cedex 2, France
}

\begin{abstract}
In the southwestern area of the Belledonne massif (external crystalline massifs, French western Alps), the finite strain pattern reflects the geometry and kinematics of Late Devonian-Late Carboniferous deformational events. Previous works suggested that the nappe stacking occurred during Late Devono-Dinantian times. New observations allow us to constrain the subsequent tectono-metamorphic evolution of the various stacked units. Westward thrusting is responsible for the early dismembering of the Rioupéroux-Livet plutono-volcanic units. Micaschist slices have also been inserted within the Rioupéroux-Livet units during this Dinantian tectonics, and have recorded metamorphic conditions of about $7-8 \mathrm{kbar}, 600-650^{\circ} \mathrm{C}$. The local NW direction of shortening is similar to the overall shortening direction recorded at this time in the Hercynian belt of western Europe. During the Late Visean, the Early Paleozoic Chamrousse ophiolite was thrust towards the northeast on top of the Rioupéroux-Livet units. The inverted geometry of the Chamrousse ophiolite may be interpreted as a consequence of this tectonics. Northeastward thrusting, also observed in the northeastern part of the French Massif Central is interpreted as the result of lateral escape in a global convergent context. Finally, the Late Carboniferous period is characterized by two extensional events: one leading to southwest dipping low-angle extensional shear zones, during the Westphalian, and a second one during the Stephanian. This latter is characterized by ductile/brittle normal faults, with a northwest-southeast direction of extension and related to the gravitational collapse of the whole Hercynian belt. (C) 2002 Éditions scientifiques et médicales Elsevier SAS. All rights reserved.
\end{abstract}

Keywords: Nappe stacking; Extensional tectonics; Hercynian belt; External crystalline massifs; Alps

\section{Introduction}

The Paleozoic orogeny resulted from the convergence between Gondwana and Laurasia [31]. In the European Paleozoic framework, the external crystalline massifs of the western Alps (Fig. 1) have for a long time been recognized as fragments of the Hercynian belt reworked during the Alpine orogenesis [1] (see also review in [2]). However, the pre-Triassic evolution of the external crystalline massifs within the Paleozoic belt is still largely debated [3-5].

In the southwestern part of the Belledonne massif, a large area of Paleozoic basement is preserved from severe reworking during the Alpine orogeny, and offers a good opportunity to study its Paleozoic tectonics and metamorphic evolution. The main structural features of the south-

\footnotetext{
* Corresponding author.

E-mail address: sguillot@univ-lyon1.fr (S. Guillot).
}

west Belledonne massif have been interpreted as nappe stacking of various units differing in the nature and ages of the protoliths [5-8]. The nappe stacking consists of from top to bottom: Cambro-Ordovician ophiolite (Chamrousse and Séchilienne units), Visean metasediments and Taillefer volcanics, Devonian to Early Dinantian metaplutonic and volcanic complex of Rioupéroux-Livet, Early Paleozoic (?) metasedimentary and amphibolitic unit of Allemont. Nappe stacking occurred during the Late Devonian to Early Carboniferous times [9] and preceded ductile and brittle extensional faulting, which is responsible for the Stephanian structuring of this domain [8]. Ductile extension is interpreted as the consequence of post-collisional extension of the Paleozoic belt and is responsible for the exhumation and local anatexis of the deepest Allemont unit [8].

This study deals with ductile and brittle pre-Triassic deformation events that affected the whole southwest Belledonne area from the base to the top of the nappe pile. Our data allow us to propose a new tectonic setting and 


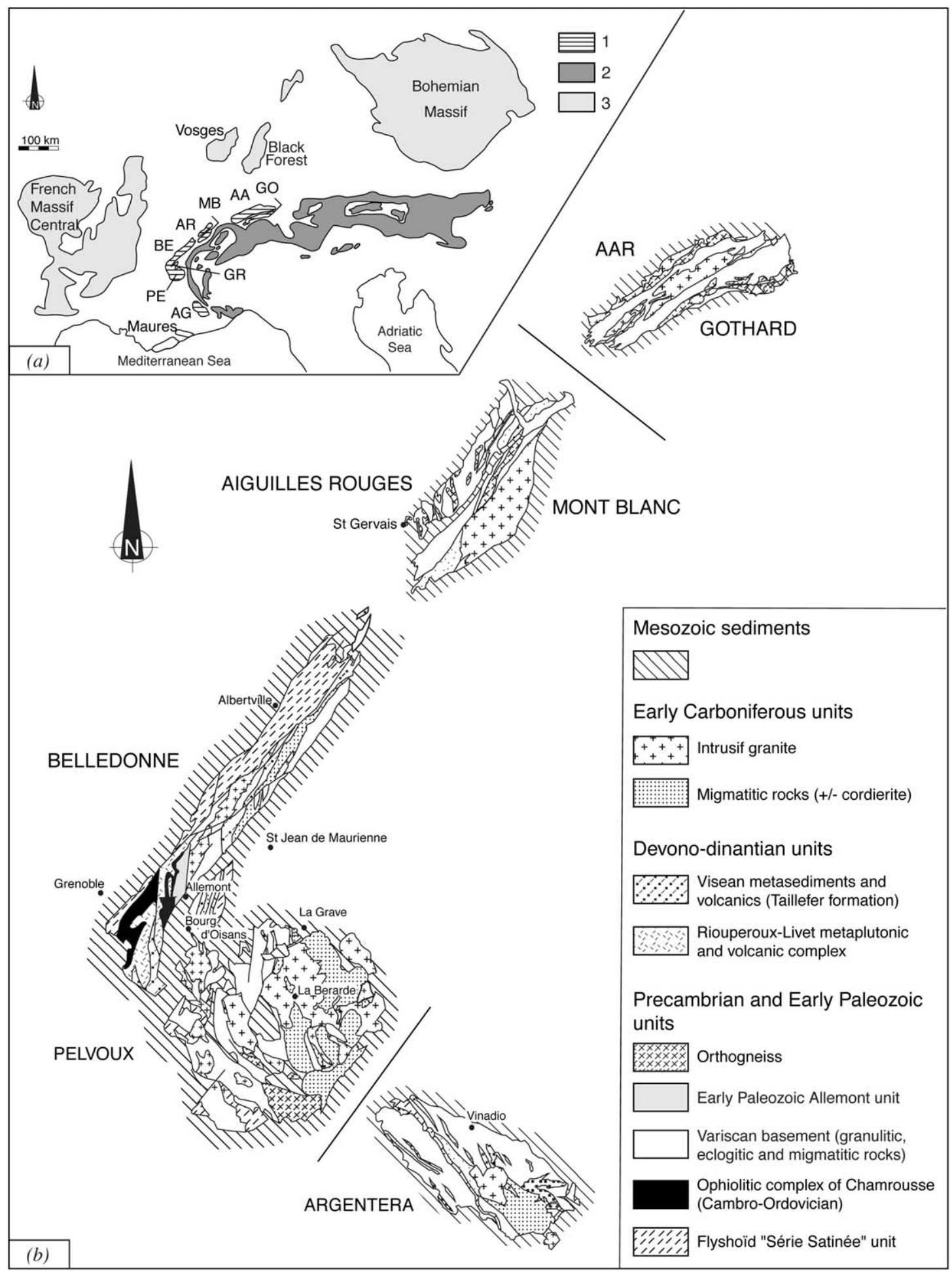

Fig. 1. (a) Hercynian basement in the Central Europe. (1) ECMs (BE Belledonne; AG, Argentera; AA, Aar; GO, Gothard; AR, Aiguilles Rouges; MB, Mont Blanc; GR, Grandes Rousses; PE Pelvoux). (2) ante-Triasic basement of Alpine arc. (3) Variscan basement of Central Europe. (b) Main geological units of ECM's (modified from [2]).

geodynamic evolution of this part of the external crystalline massifs from Late Devonian to Late Carboniferous. Assuming that the Belledonne massif has not rotated during the
Alpine orogenesis [10], we propose to integrate directly the Belledonne massif within the framework of the Hercynian evolution during the Late Paleozoic. 


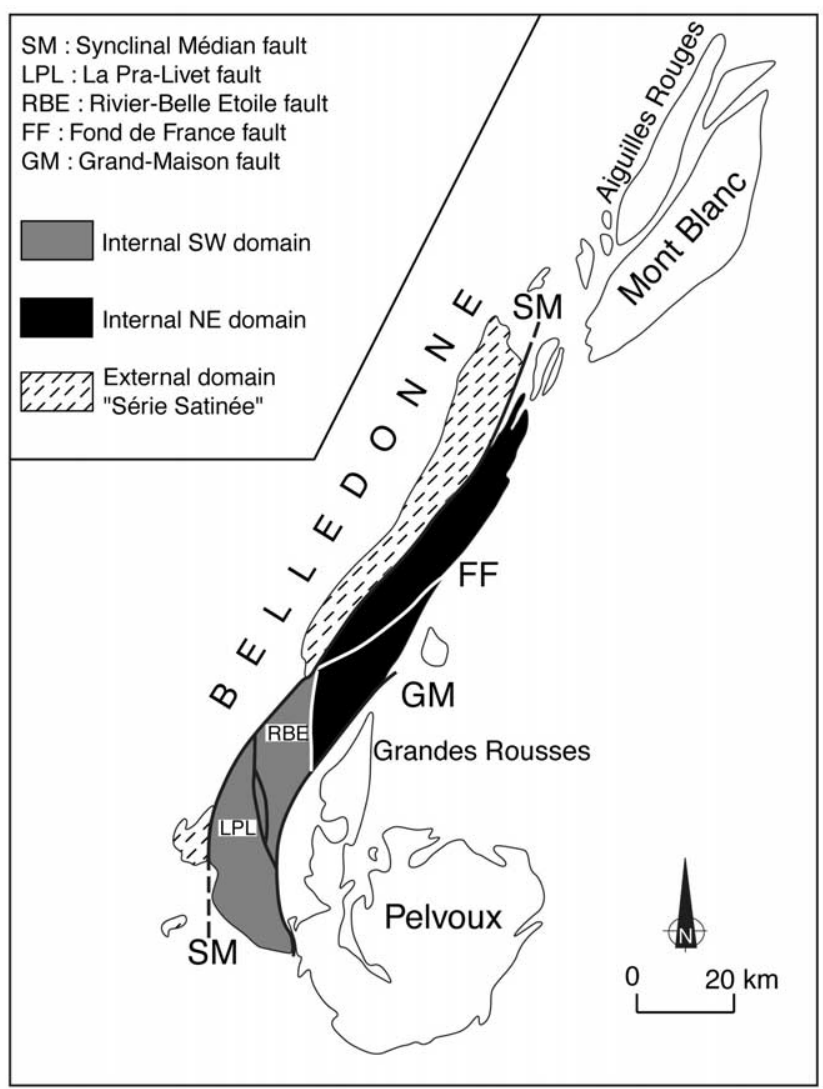

Fig. 2. Geological sketch map of the Belledonne Massif (modified after [38]).

\section{Geological setting}

The Belledonne massif comprises two major tectonic and metamorphic domains, called the external and internal domains. They are separated by the Late Hercynian dextral Synclinal Médian strike-slip fault, which was reactivated as a dextral Alpine fault (Figs. 1 and 2). Within the internal domain, Ménot [3] distinguished a northeastern and a southwestern domain separated by a north-south Late Devonian sinistral trending shear zone, the Rivier-BelleEtoile fault [11] (Fig. 2).

The external domain (Figs. 2 and 3) is built up by a sub-vertical metapelitic series (série satinée) including: chloritic-, sericitic- and graphito-schists associated with surbordinate quartzites and amphibolites. This series displays a polymetamorphic imprint and an Early Paleozoic age has been proposed for the protolith by analogy with similar series in the southern French Massif Central [12,13].

The northeastern internal domain (Figs. 2 and 3) includes a gneissic and amphibolitic basement crosscuts by Carboniferous synkinematic granites [14]. This basement recorded a long-lived tectonic and metamorphic evolution [2] with mineralogical evidence of a Late Silurian-Early Devonian eclogitic facies metamorphism $(390 \pm 8 \mathrm{Ma}, \mathrm{U} / \mathrm{Pb}$ on zircon; [15]), followed by granulitic to amphibolitic retrogression.
These successive stages are related to a Siluro-Devonian subduction and crustal thickening processes [11]. During the Early Carboniferous, this domain was subjected to pervasive sinistral wrenching contemporaneous with granitoid emplacement [11,14].

The southwestern internal domain consists of a nappe pile (Fig. 4) (see review in [7]). The upper part comprises the Chamrousse ophiolitic complex, which is characterized by a westward dipping tabular structure on the western side and a strongly folded nappe structure on the eastern side of the La Pra-Livet fault. This oceanic crust fragment of Cambro-Ordovician age $(496 \pm 6 \mathrm{Ma}$ by U/Pb, [16] and $497 \pm 24 \mathrm{Ma}$ by $\mathrm{Sm} / \mathrm{Nd}$ [17]) was generated on a slowspreading ridge, within a marginal basin $[18,19]$. It is now lying in an inverted stratigraphic position upon DevonoDinantian units [7]. The intermediate part of the nappe pile is built up by several subunits belonging to the Upper Devonian-Early Dinantian Riouperoux and Livet units that represent remnants of a continental rift or of an active margin $[7,15]$, and by the Late Dinantian (Visean) intracontinental metasedimentay Taillefer basin [3,6]. These Devono-Dinantian units are considered to be a volcanosedimentary and plutonic complex, tectonically dismembered before and during the overthrusting of the Chamrousse ophiolitic complex [3]. The upper and intermediate units of the nappe pile display a monometamorphic imprint at greenschist to amphibolite facies condition, which is Late Devonian to Late Dinantinian in age [2,9]. The nappe stacking is bracketed between $362 \pm 4 \mathrm{Ma}(\mathrm{U} / \mathrm{Pb}$ age of igneous protoliths in the Rioupéroux and Livet units [15]) and $324 \pm 12 \mathrm{Ma}$ (K/Ar cooling ages of amphiboles [9]). The base of the nappe pile consists of the Allemont unit. The Allemont unit consists mainly of paragneisses with minor intercalations of amphibolites and orthogneisses [20]. According to the contrasted metamorphic evolution, Guillot and Ménot [8] distinguished an Allemont upper sub-unit and an Allemont lower sub-unit. The Allemont upper sub-unit preserves an earlier HP-MT metamorphism (D1) before the common D2 barrovian metamorphism. The rapid exhumation controlled by extentional tectonics towards the southwest led to local synkinematic melting in the Allemont lower sub-unit.

\section{Structural analysis}

Mapping of foliations and stretching lineations observed in the southwestern part of the Belledonne massif, mainly within the Upper Devonian and Early Carboniferous units, are presented in Fig. 5. Various kinematics indicators have been recognized in the deformed Devonian-Dinantian units such as re-orientation and transposition of foliation plane [21], asymmetric shear bands and drag microfolds. Successive stages of deformation have been recognized from D1 to D4. 


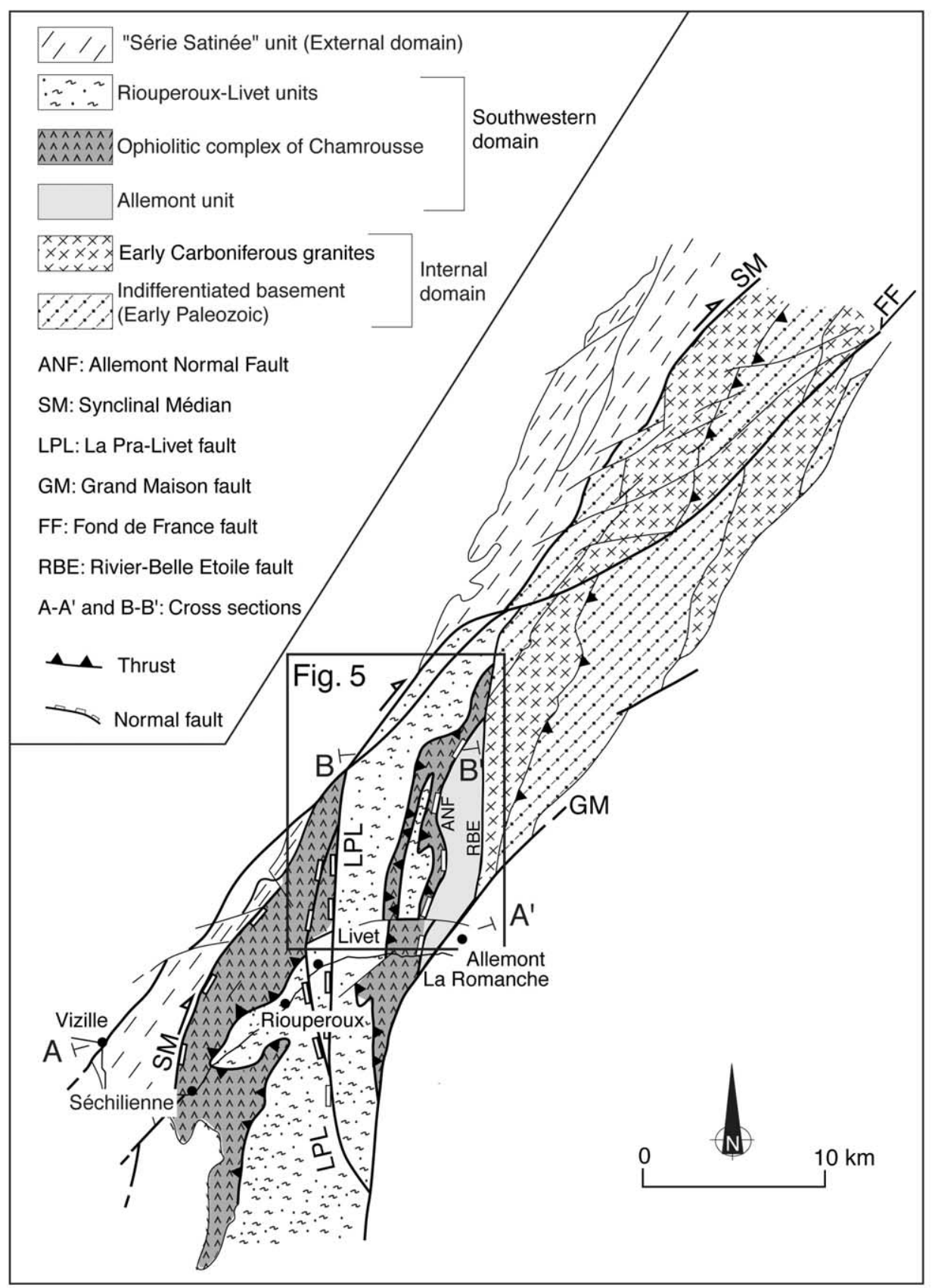

Fig. 3. Geological map of southwest Belledonne massif (modified after [3]) with the location of the A-A' (Fig. 4) and B-B' (Fig. 6) cross-sections.

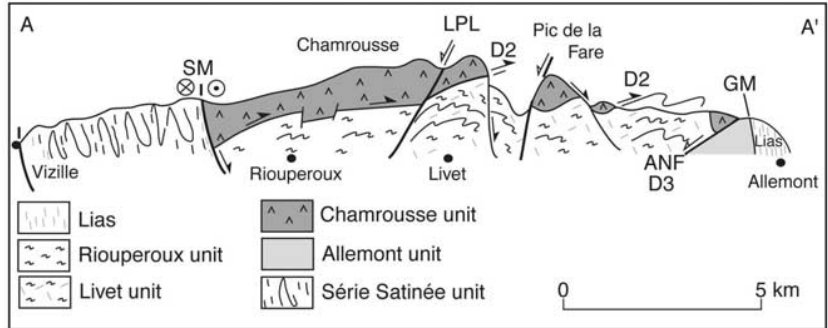

Fig. 4. A-A' cross-sections of the southwest Belledonne massif (modified after [3]).

\subsection{D1 structures and microstructures within the Devono- Dinantian units}

Major D1 km-scale recumbent folds have been observed in the felsic, amphibolitic and metapelitic series of the Devono-Dinantian units. They show opposite vergency, to the west and to the east on the western and eastern flanks of the Ferrouillet crest, respectively (Fig. 6 [20]). On the western flank of the Ferrouillet crest, no pre-metamorphic, igneous relics, minerals or structures have been preserved, and amphibolites display the $\mathrm{S} 1$ foliation, related to the earliest tectonic event D1. The angle between the stratification within the Triassic unit and the $\mathrm{S} 1$ foliation in the 


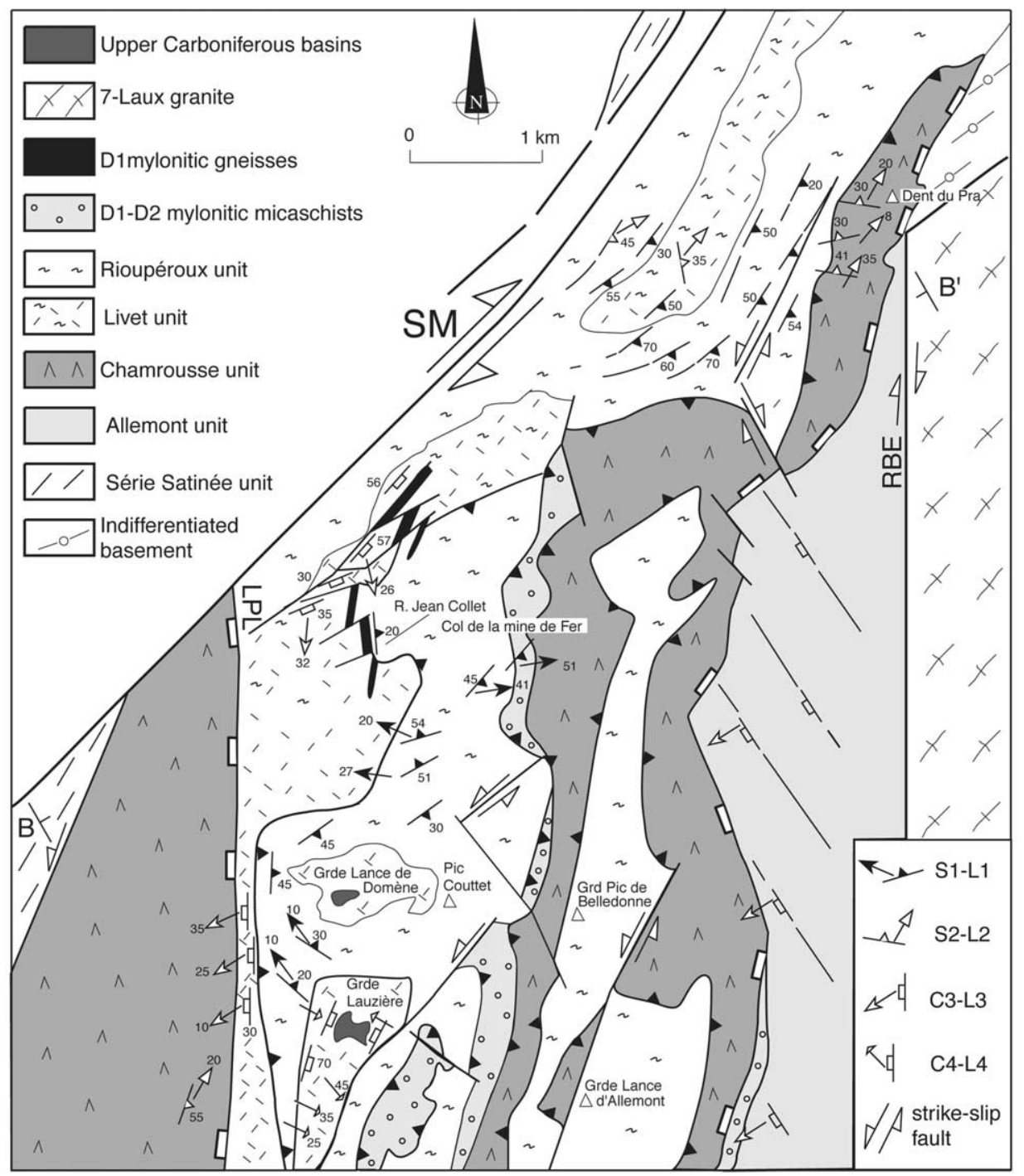

Fig. 5. Structural sketch map of the southwest Belledonne massif (modified after [20]). (1) Strike and dip of S1 foliation and L1 lineation; (2) strike and dip of S2 foliation and L2 lineation at the base of the Chamrousse ophiolite; (3) strike and dip of S3 foliation and L3 lineation; (4) strike and dip of S4 fault and L4 lineation; (5) Late Hercynian and Alpine strike slip faults. SM Synclinal Médian; LPL La Pra Livet fault; RBE Rivier-Belle Etoile fault. The Fig. 6 is located on B-B'.

amphibolites shows that this latter is tilted towards the west at a minimum of $20^{\circ}$ at the regional scale. In the felsic gneisses and amphibolites, the regional S1 foliation dips roughly to the east and is associated with an early L1 mineral lineation underlined by preferred orientation of plagioclase and amphibole. The trend of L1 varies from $\mathrm{N} 90^{\circ}$ to $\mathrm{N} 130^{\circ}$ but may be locally reoriented close to late strike-slip faults. In mylonitic micaschists, the L1 lineation is marked by the preferred orientation of staurolite and kyanite, and is oriented $\mathrm{N} 90^{\circ}$. $\mathrm{F} 1$ microfolds and $\mathrm{C} 1$ shear bands are underlined by quartz ribbons and feldspar clasts (Fig. 7). The S1 foliation and the stretching lineation L1 are parallel to the axial cleavage plane and sub-perpendicular to the hinge of F1 microfolds, respectively. Shear criteria, asymmetry of the drag folds and shear bands, indicate a top to the west or northwest motion during D1.
From the 'Refuge Jean Collet' up to the 'Col de la Mine de Fer' (Fig. 6), the micaschists intercalated within the Devono-Dinantian unit are intensively deformed and represent a $\mathrm{N} 20^{\circ}$-directed mylonitic zone. This hectometric mylonitic zone is characterized by the presence of F1 drag microfolds and $\mathrm{C} 1$ east-dipping shear bands. We propose that the early tectonic event D1 corresponds to the thrusting of the Rioupéroux unit over the Livet unit towards the west or the northwest. The intercalation of micaschist slices within the thrust zone seems to be contemporaneous to D1.

\subsection{The D2 tectonic sole of the Chamrousse ophiolitic complex}

The core of the Chamrousse ophiolite is characterized by well-preserved intra-oceanic deformations related to oce 


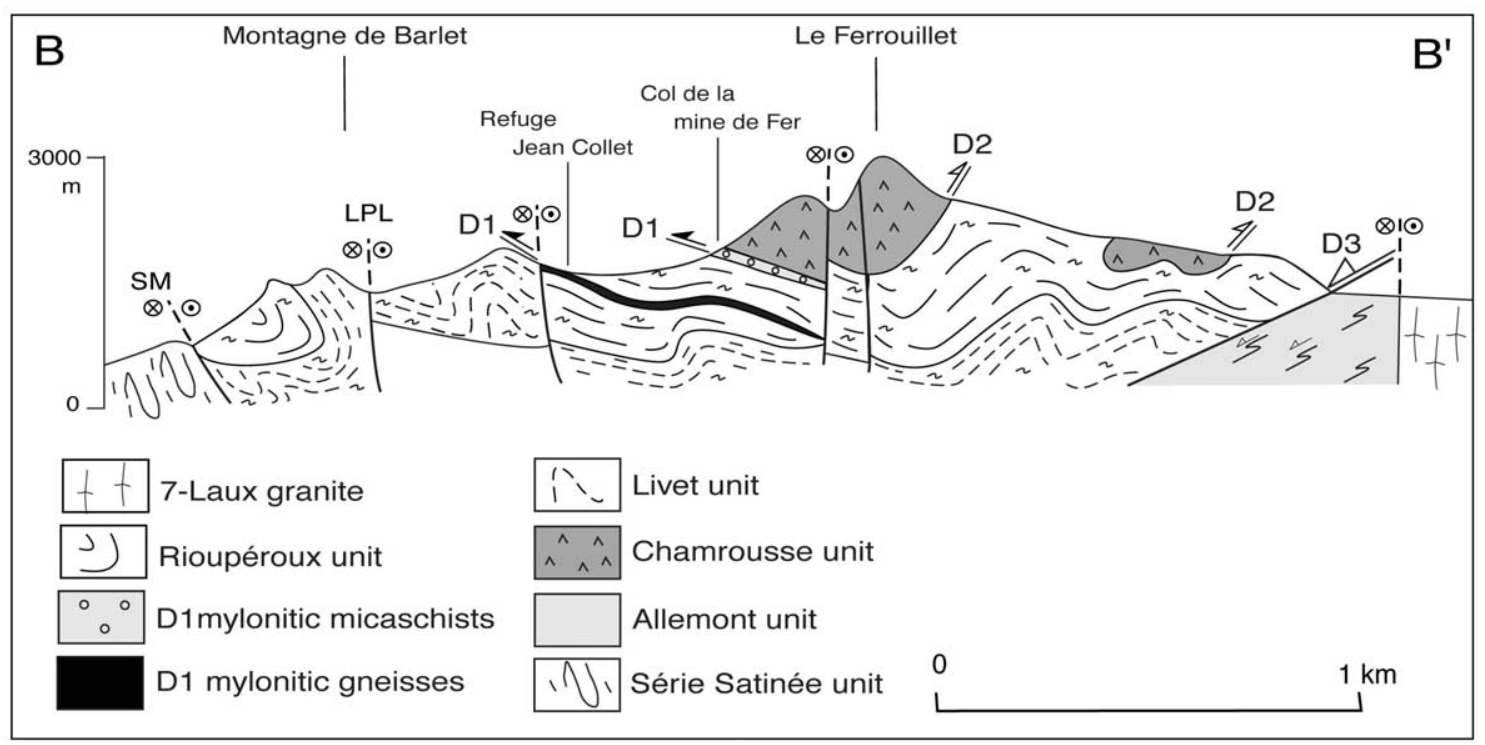

Fig. 6. B-B' cross section from Rioupéroux-Livet units up to the Allemont unit, throughout the Chamrousse ophiolite (modified after [20]).

anic rifting [19]. In contrast, the sole of the ophiolite, hectometric to kilometric in thickness, is a mylonitic zone that formed during thrusting on the top of the Rioupéroux-Livet units. In the 'Dent du Pra' area, amphibolites belonging to the ophiolitic complex are characterized by the development of a main S2 foliation roughly oriented N95 $25^{\circ} \mathrm{N}$, which is superimposed on the locally reoriented $\mathrm{S} 1$ foliation (N30 54 ${ }^{\circ} \mathrm{SE}$ ) (Fig. 8a). All along the southwestern part of the Belledonne massif, the mineral lineation L2 is oriented $\mathrm{N} 3025^{\circ} \mathrm{NE}$ and is marked by the preferred orientation of plagioclase and amphibole. The felsic layers in amphibolites show F2 drag microfolds (Fig. 8b) roughly oriented $\mathrm{N} 130^{\circ}$ and asymmetric felsic eyes (Fig. 8c) indicating top to the northeast sense of shear. The constant direction of L2, at the regional scale, represents the direction of transport towards the northeast. Below the Chamrousse ophiolite, in the Rioupéroux and Livet units, D2 is particularly well developed. An S2 cleavage is observed parallel to the mean orientation of axial planes of D2 folds with an average direction of $\mathrm{N}-\mathrm{S} 40^{\circ} \mathrm{W}$ [8]. The hinge of

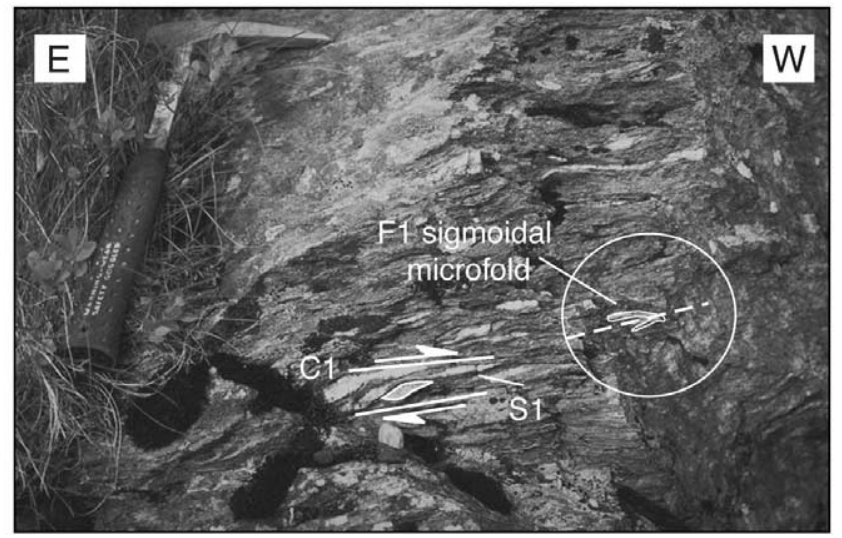

Fig. 7. C1 shear bands and F1 sigmoidal microfolds in the Devonian-Early Carboniferous felsic gneisses (Lac Blanc). these folds strikes parallel to the S1-S2 intersection lineation with a $\mathrm{N} 17525^{\circ} \mathrm{N}$ orientation. The reorientation of the $\mathrm{S} 1$ plane by $\mathrm{C} 2$ shear planes indicates a top to the northeast motion. Scattered shear criteria at the base of the nappe pile, also indicate a thrusting of the Allemont upper subunit over the Allemont lower subunit towards the northeast [8].

South of the Romanche river (Fig. 3), three main lithological subunits were recognized with, from top to bottom: (i) the ophiolite of Chamrousse, (ii) the DevonoDinantian units including the 'micaschistes des Roberts' and (iii) the Visean metaconglomerates of the Taillefer unit. A spectacular cross-section across the southern flank of the Romanche river exhibits mesoscopic northeastward verging folds (Fig. 9). The dominant planar structure observed within the Taillefer black schists appears as a composite $\mathrm{S} 1-\mathrm{S} 2$ crenulation cleavage. In these schists, the intersection lineation between $\mathrm{S} 1$ and $\mathrm{S} 2$ is parallel to the microfold axes of the crenulation with a N140 $10^{\circ} \mathrm{SE}$ trending direction. The microfolds show a northeastern vergence similar to that observed in the amphibolites of the sole of the ophiolitic unit. The axial planes of F2 microfolds are parallel to those of mesoscopic folds. Thus, geometric features of F2 microfolds fit with those of major fold structures and we propose that they are both related to the D2 tectonic event. On both sides of the Romanche river, the D2 tectonic episode is responsible for the northeastward thrusting of the Chamrousse ophiolite at the top of the nappe pile, upon the Taillefer and Riouperoux-Livet units.

\subsection{D3 SW-NE deformation}

D3 deformation is localized and superimposed on the earlier D1-D2-related structures. Based on microstructural investigations and the geometrical relationships between the Carboniferous deposits and the deformation, we propose 

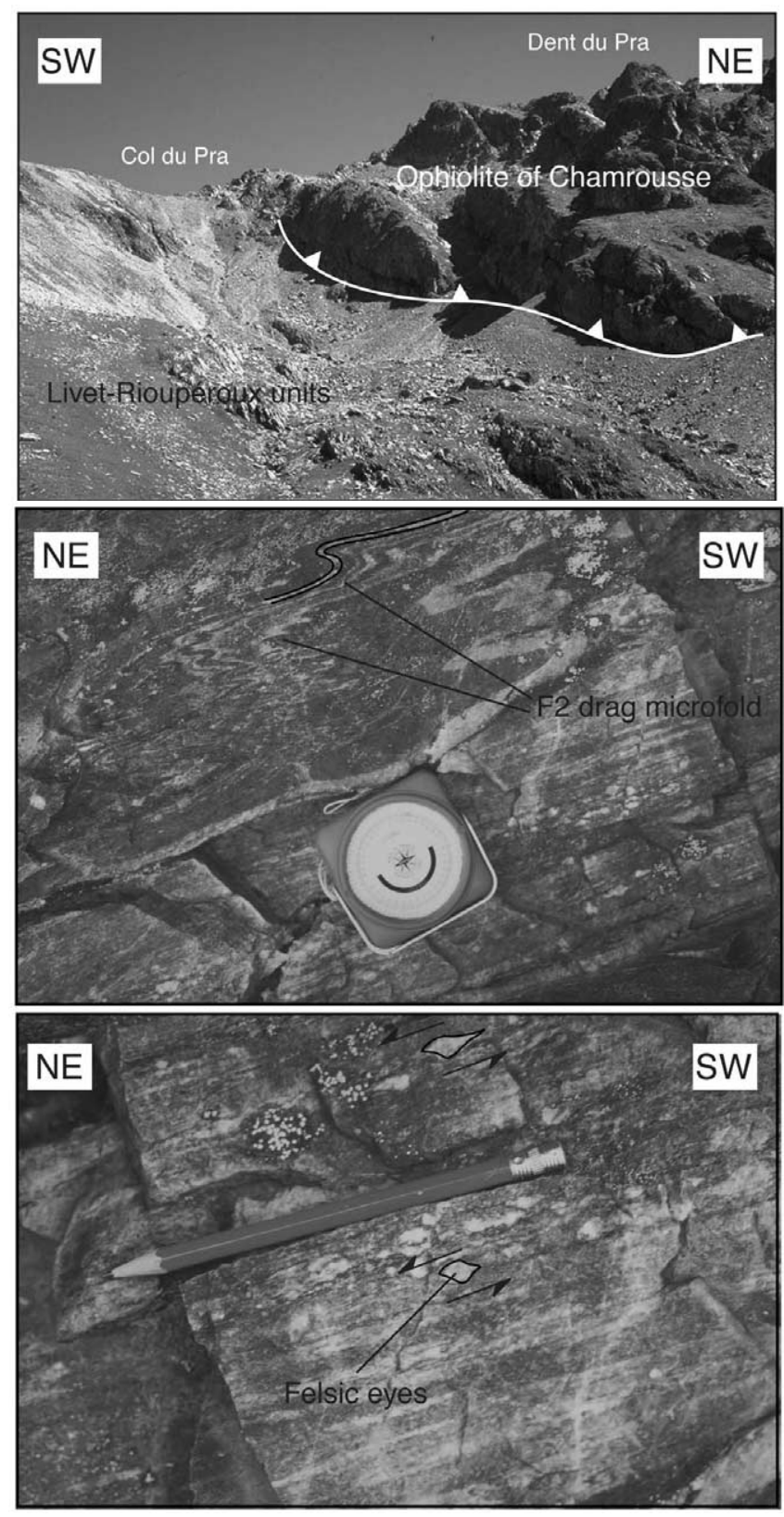

Fig. 8. (a) General view of the thrust contact between the Chamrousse ophiolite and the Rioupéroux-Livet units (Dent du Pra). (b) F2 drag microfolds in amphibolite from the sole of the Chamrousse ophiolite (Dent du Pra). (c) $\sigma$-Type structures underlined by feldspar eyes in amphibolites from the sole of the Chamrousse ophiolite (Dent du Pra).

that these structures resulted from Late Carboniferous crustal evolution.

At the base of the nappe pile, tectonics is characterized by pervasive development of regularly-spaced C3 shear bands oriented $\mathrm{N} 15060^{\circ} \mathrm{SW}$. The relationships between $\mathrm{C} 3$ shear bands and the $\mathrm{S} 2-\mathrm{S} 3$ foliation plane indicate a top to the southwest direction of extension that leads to local decompression and melting of the Allemont lower subunit characterized by the development of hectometric batches of cordierite-bearing anatexites [8].
In the deepest levels of the Riouperoux-Livet units, the amphibole facies fabric $\mathrm{S} 1$ is overprinted by discrete muscovite-chlorite-bearing C3 shear bands in the micaschists (Fig. 10). The C3 shear bands are characterized by a strike ranging between $\mathrm{N} 90$ and $\mathrm{N} 120^{\circ}$ dipping to the south or to the southwest at about $40-60^{\circ}$. A greenschist facies L3 lineation varies from N-S $25^{\circ} \mathrm{S}$ to N70 displacement towards the south or the southwest (Fig. 11). Where the D3 deformation is penetrative, C3 shear bands form a southwestward dipping detachment as observed at the contact between the Allemont unit and the Chamrousse unit (Fig. 5).

In the middle part of the nappe pile, the D3 event is characterized by the development of localized ductile-brittle structures at metric scale. A cross-section from the 'Grande Lance de Domène' to the 'Pic Couttet' (Fig. 12) shows that the $\mathrm{S} 1$ foliation plane has a sigmoidal shape throughout the $\mathrm{C} 3$ shear bands, indicating that the basement is affected by a ductile/brittle extensional faulting which dips towards the southwest. The finite geometry of the Carboniferous sedimentary basin of the 'Grande Lance de Domène' (Westphalian D conglomerates according to Carme [12]) is controlled by the D3 normal fault (Fig. 12), suggesting that the detrital sedimentation is syn-extension.

\subsection{D4 NW-SE extension and strike-slip faults}

Major extensional and strike-slip faults are responsible for the late structuring of the southwestern Belledonne massif. In the Devono-Dinantian units, the deformation is characterized by conjugate D4 ductile faults oriented N40 $30^{\circ} \mathrm{NW}$ or $\mathrm{N} 4030^{\circ} \mathrm{SE}$ (Fig. 13) and associated with development of chlorite- and muscovite-bearing lineation oriented N120 $20^{\circ} \mathrm{NW}$ or N120 $20^{\circ}$ SE. Geometrical relationships between $\mathrm{C} 4$ shear bands and $\mathrm{S} 1$ or $\mathrm{S} 2$ foliations show low-angle normal fault displacement top to the northwest or the southeast. At the top of the nappe pile, the Stephanian A sedimentary basin of 'La Grande Lauziere' [12] is characterized by a fan-shape geometry of deposits and is limited by normal faults dipping to the northwest or to the southeast. They juxtapose the Stephanian A deposit against the amphibolite facies rocks of the DevonoDinantian units. Locally, $\mathrm{N} 40^{\circ}$ normal faults are reactivated in sinistral strike-slip displacement oriented $\mathrm{N} 40^{\circ}$ as exemplified by the La Pra-Livet fault. West of the La Pra-Livet fault, the Rioupéroux-Livet units are cut by other sinistral strike-slip faults along a northeast-southwest line, suggesting that the strike-slip faults postdate, in this case, the Stephanian sedimentation. These $\mathrm{N} 40^{\circ}$ sinistral strike-slip faults are conjugated with the $\mathrm{N} 70^{\circ}$ dextral strike-slip fault that developed at the regional scale (Fig. 3).

At the scale of the study area, the successive outcropping of the Chamrousse ophiolite, the Rioupéroux-Livet units and the Allemont unit from west to east can be interpreted as the result of unroofing of the deepest part of the nappe 


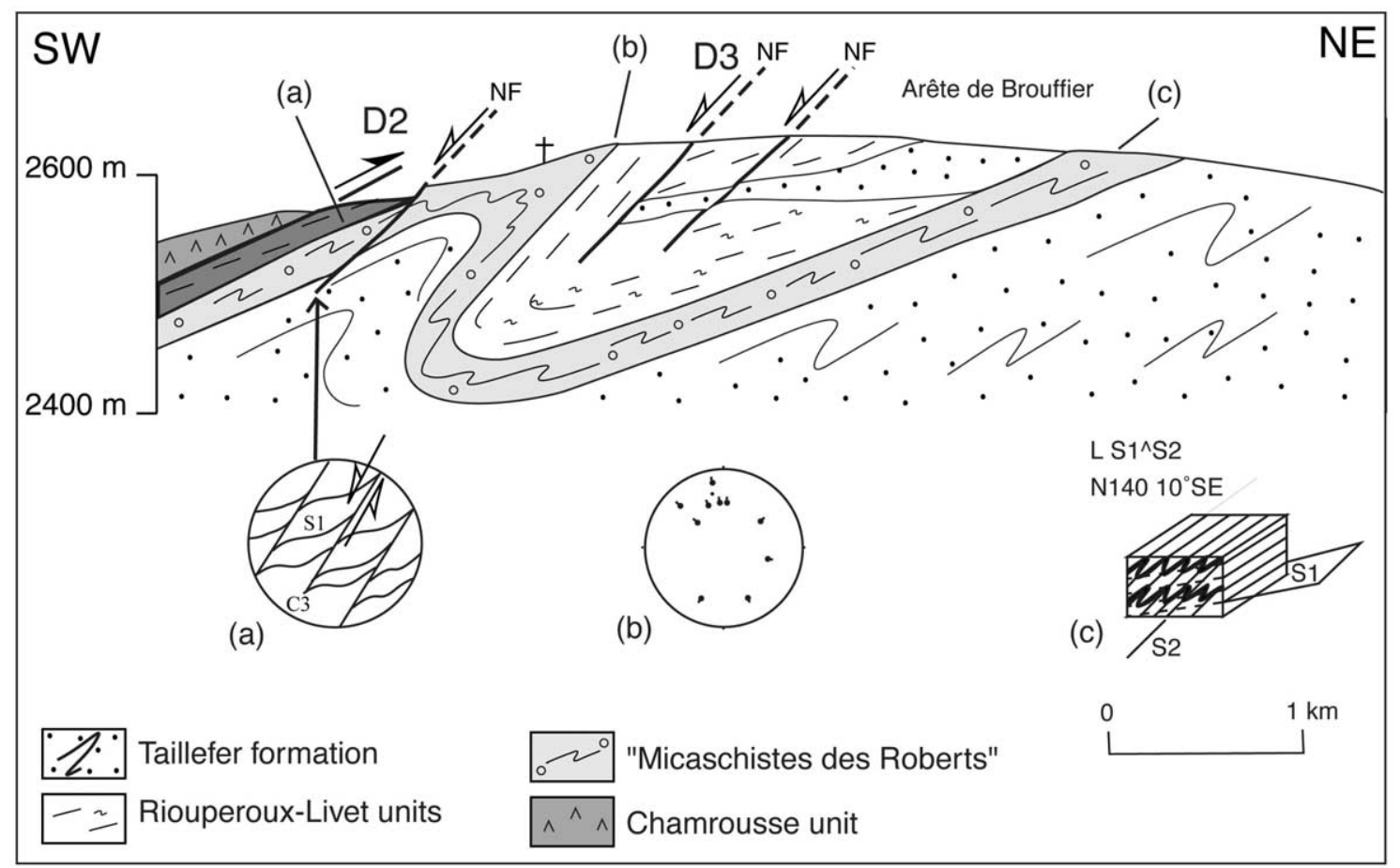

Fig. 9. Cross-section on the southern flank of the Taillefer unit showing kilometric folds with a northeastern vergence. (a) Fabric S1-C3 showing a normal motion toward the SW. (b) Hinge line of the F2 microfolds associated to the S2 crenulation cleavage (best axis N168 20 NW). (c) Fabric S1-L1 transposed by S2-L2 fabric showing top to the northeast sense of shear.

pile towards the east during the D3 and D4 extensional tectonics.

\section{Metamorphic evolution}

In order to compare the thermobarometric analysis provided [8] at the base of the nappe pile, we have evaluated the $P-T$ conditions in the mylonitic gneisses and micaschists tectonically placed between the Roupéroux and Livet units. In the micaschists, staurolite and garnet represent relict minerals and have been partly obliterated by

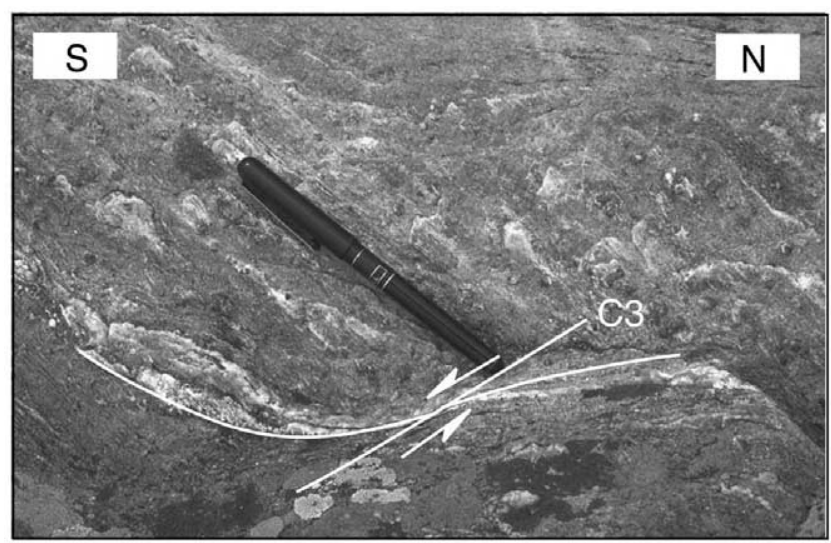

Fig. 10. C3 extensional shear bands oriented $\mathrm{N} 12038^{\circ} \mathrm{SW}$ in the deepest level of the Devonian-Early Carboniferous units. C3 extensional shear bands oriented N120 $38^{\circ} \mathrm{SW}$ in the deepest level of the Devonian-Early Carboniferous units. kyanite + biotite assemblage, typical of D2 deformation [8] and by D3 assemblage, characterized by a muscovite + chlorite + quartz mineral association. The composite S1-S2 foliation of mylonitic gneisses is underlined by almandine-rich garnet, biotite and staurolite. Kyanite is not observed in the studied samples probably due to the relatively poor $\mathrm{Al}$ content of these gneisses. The garnets are sub-millimetric and form aggregates aligned in the main foliation. XFe of biotites and staurolite are 0.50 and 0.83 , respectively. Rutile appears as inclusion within garnet. Plagioclase also underlines the $\mathrm{S} 1$ foliation, high $\mathrm{XAb}$ ranging between 0.71 and 0.79 , suggesting that the plagioclase was re-equilibrated during a retrogressed stage. In

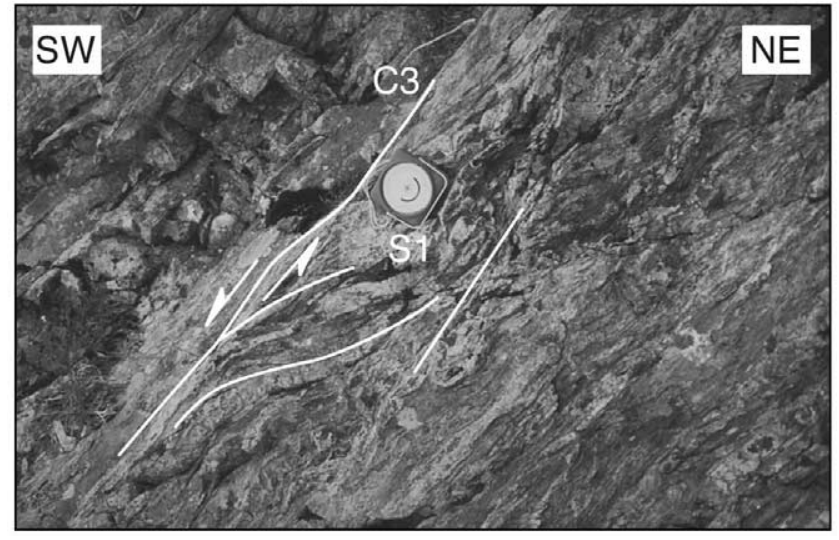

Fig. 11. Kinematics of the $\mathrm{C} 3$ shear bands crosscutting the $\mathrm{S} 1$ foliation near the 'Refuge de la Pra'. Noticed that C 3 and S1 were tilted towards the West during Alpine deformation. 

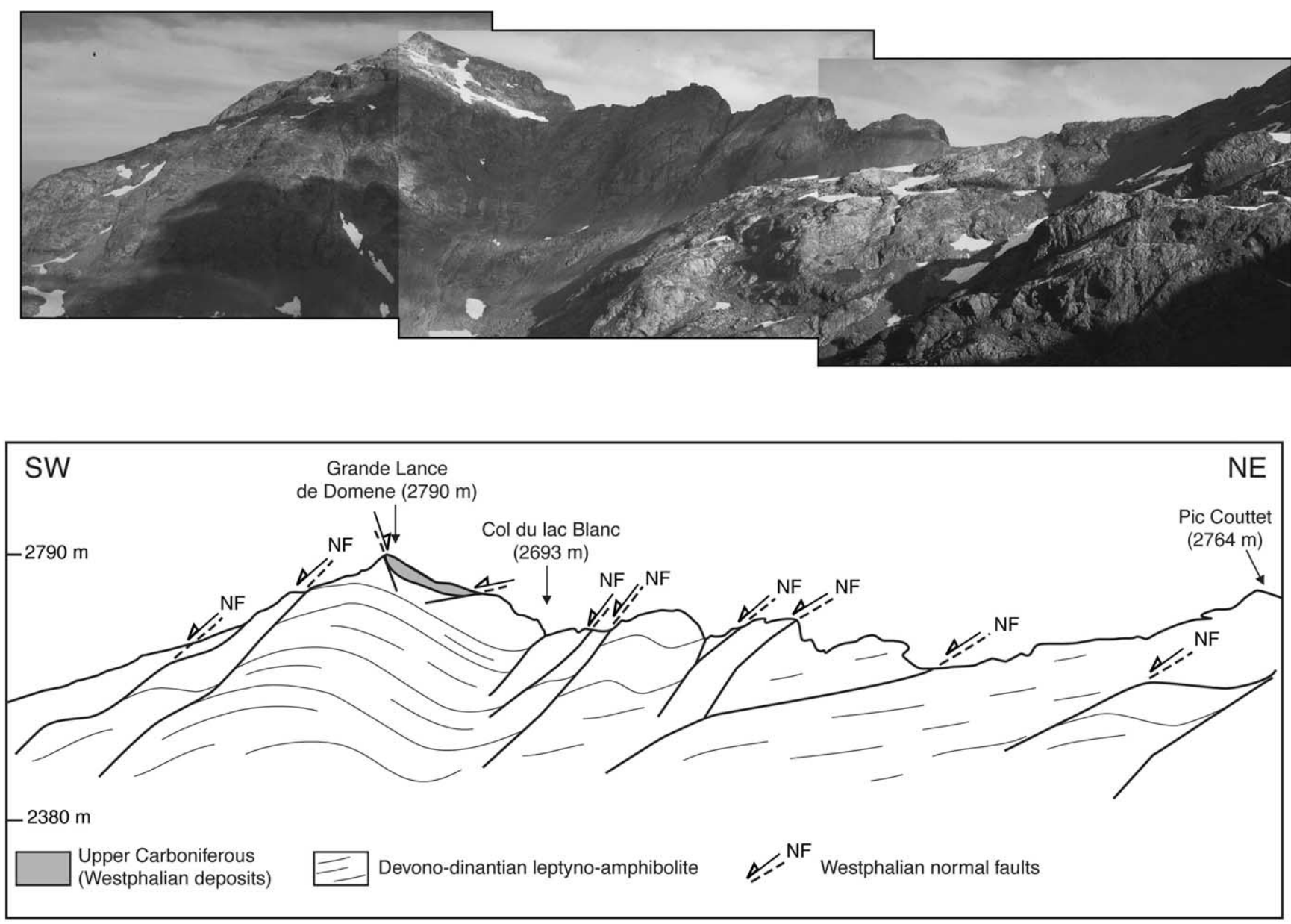

Fig. 12. Cross-section through the 'Grande Lance de Domène' with sigmoidal S1 foliation plane crosscuts by C3 shear bands related to ductile normal faults indicating southwestward extensional movement.

summary, three parageneses have been recognized in the different micaschists and gneissic slices: the early D1 assemblage consists of garnet $1+$ biotite $1+$ staurolite $1+$ plagioclase + quartz + rutile. The D2 assemblage observed just below the sole of the Chamrousse ophiolite consists of the apparition of the kyanite + biotite assemblage at the expense of staurolite 1 in the micaschists or the garnet $2+$ staurolite 2 assemblage in the mylonitic gneisses. The latest stage is superimposed on all the previous textures during D3 at greenschist facies conditions, and it consists of a biotite + muscovite + chlorite + albite + quartz mineral association.

To estimate the $P-T$ conditions of the D1 we have used thermometers based on the $\mathrm{Fe}-\mathrm{Mg}$ exchange between garnet and biotite [22,23], $\mathrm{Fe}-\mathrm{Mg}$ exchange between garnet and staurolite [24] and the garnet-plagioclase-biotite-quartz barometer [25]. These results were compared with those obtained with Thermocalc [26]. Table 1 summarizes the results which are given with $2 \sigma$ uncertainties.

Conventional thermobarometry and Thermocalc suggest average $P-T$ conditions of $7 \pm 2 \mathrm{kbar}$ and $615 \pm 80^{\circ} \mathrm{C}$ for the syn D1 assemblage of the metapelites of the Refuge Jean Collet and comparable values $\left(9 \pm 2 \mathrm{kbar}\right.$ and $\left.620 \pm 20^{\circ} \mathrm{C}\right)$ for the Col de la Mine de Fer tectonic slice.
$P-T$ conditions of the syn-D2 assemblage are well constrained at $5 \pm 1 \mathrm{kbar}$ and $520 \pm 40{ }^{\circ} \mathrm{C}$ in the 'Micaschistes des Roberts', in the Taillefer unit, just below the Chamrousse ophiolite.

When compared with values proposed by [8] for rocks located at the intermediate part and at the base of the nappe pile (Allemont and Livet units), the pressure conditions are slightly lower during D1 (2 kbar) and significantly lower during D2 (3 kbar). This discrepancy remains compatible with the higher structural level of the newly studied samples. We propose that the micaschist slices of the southwest Belledonne massif derive from a single tectonometamorphic unit subjected to contrasted pressure conditions during D1 and D2 tectonic events and later dismembered during the extensional Carboniferous tectonics.

During the D3 extensional tectonics, $P-T$ conditions at the base of the nappe pile were 4-6 kbar and $600-700{ }^{\circ} \mathrm{C}$ with local anatexis [8], whereas at upper structural levels, only greenschist facies minerals are observed suggesting $P-T$ conditions of about $300-400{ }^{\circ} \mathrm{C}$ and $2-4$ kbar. Therefore, a transitional evolution from anatectic to greenschist facies conditions may be observed from the base to the top of the $3000 \mathrm{~m}$-thick nappe pile, during the D3 ductile 


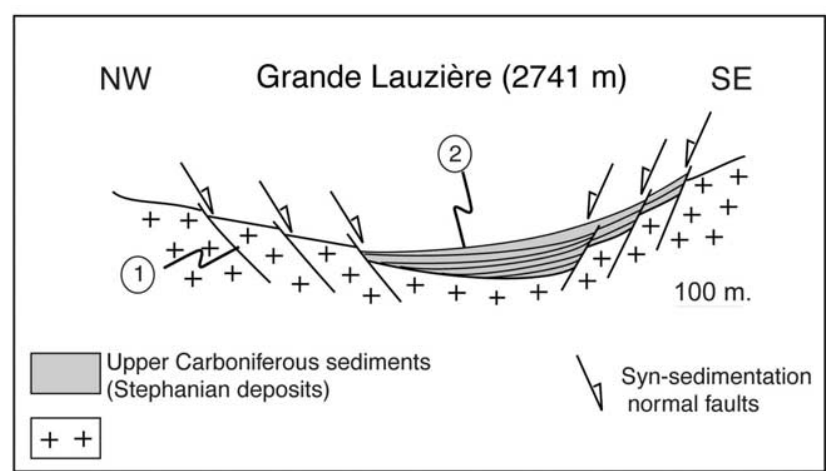

(a).-
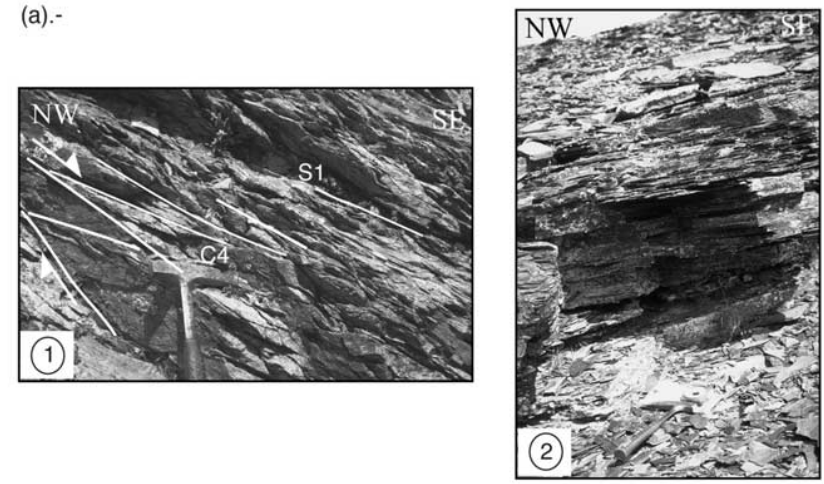

Fig. 13. Basin of the 'Grande Lauzière' showing D4 northwest-southeast brittle extension characterized by conjugated D4 faults oriented N40 $30^{\circ} \mathrm{NW}$ or $\mathrm{N} 4030^{\circ} \mathrm{SE}$. (a) Cross section throughout the half graben showing the extension directions in the basement and the fan-shape geometry of the Stephanian deposits. (1) Detail of D4 microstructures in the basement showing C4 normal faults oriented N40 30 $\mathrm{SE}$; (2) detail of Stephanian deposits in the half graben with S0 bedding oriented N45, $20^{\circ} \mathrm{W}$.

shearing event. This reflects the vertical decrease of temperature, i.e., a finite apparent thermal gradient of about $100-130{ }^{\circ} \mathrm{C} / \mathrm{km}$. Such values are typical of the thermal conditions recorded all along the Paleozoic belt of Europe during the late orogenic extension [27].

\section{Discussion}

The tectonic features and the timing of deformation put forward new constraints on the evolution and setting of the southwestern Belledonne massif within the Hercynian framework.

A major stacking episode related to Mid-Paleozoic (400-360 Ma) nappe tectonics is exemplified by the tectonic and metamorphic evolution of the northeastern domain of
Belledonne and most parts of the external crystalline massifs [2]. Thus, the northeastern domain of Belledonne may be considered as representative of the inner part of the Hercynian Belt [7]. The external zones of the orogenic belt were involved in the collision zone only during the Early Carboniferous and the nappe stacking was completed before Middle Visean times [9]. In the southwestern Belledonne massif, the Late Paleozoic period (360-295 Ma) is characterized by successive phases of deformation. According to the age of the late Devonian trondjhemite intrusions of Livet (352 \pm 55 and $367 \pm 17 \mathrm{Ma},[15])$ and the cooling stage dated by K/Ar on hornblende at $324 \pm 12$ [9], we propose a Dinantian age for the D1 northwestward thrusting event. During the same period, the northeastern domain of Belledonne, also recorded a northwestward thrusting with a sinistral component along the $\mathrm{N} 30^{\circ}$ wrench fault, contemporaneous with the emplacement of the $\mathrm{Mg}-\mathrm{K}$ granitoids $[11,14]$. The northwestward direction of thrusting observed in the Belledonne massif is in good agreement with the common shear direction and kinematic indicators within the French Massif Central and the Armorican massif during the same period [28-30] (Fig. 14).

At the end of the Dinantian, a second shortening event is responsible for the northeast directed thrusting of the Chamrousse ophiolitic complex upon the Devono-Dinantian units. The development of large folds during D2 as observed in the Taillefer area can explain the inverted stratigraphic position of the Chamrousse ophiolite. The cooling stage dated by $\mathrm{K} / \mathrm{Ar}$ on hornblende at $324 \pm 12 \mathrm{Ma}$ [9] gives a maximum age for the D2 event. This Visean tectonic has also been recently recognized in the northeastern part of the French Massif Central [29,30]. At the same time, the southern part of the Iberian block records thrusting towards the southwest whereas the northern part of the IberoArmorican arc still continues to record compression towards the northwest [31]. Thus, we propose to relate the D2 event to the lateral escape of the Hercynian blocks located north and south of the Ibero-Armorican arc (Fig. 14) as observed in the present-day western Himalayan syntaxis [32].

Shortening (D1 and D2 events) is followed in the southeastern part of the Belledonne massif by two extensional tectonic events (D3 and D4). The D3 extensional event has been first recognized in the Allemont unit and in the micaschists at the base of the tectonic pile $[8,20]$. It is characterized by an extensional shear zone oriented roughly $\mathrm{N} 150^{\circ}$ and dipping $60^{\circ}$ towards the southwest. The kine-

Table 1

$P-T$ estimates of the Belledonne micaschists

\begin{tabular}{|c|c|c|c|c|c|c|c|}
\hline Location & Sample & Parageneses & Def & $\begin{array}{l}P \text { Thermo } \\
\text { (kbar) }\end{array}$ & $\begin{array}{l}T \text { Thermo } \\
\left({ }^{\circ} \mathrm{C}\right)\end{array}$ & $\begin{array}{l}P \text { Conv } \\
\text { (kbar) }\end{array}$ & $\begin{array}{l}\text { T Conv } \\
\left({ }^{\circ} \mathrm{C}\right)\end{array}$ \\
\hline Refuge Jean Collet & $382-15$ & $\mathrm{Grt} 1+\mathrm{St} 1+\mathrm{Bt} 1+\mathrm{An}+\mathrm{Qtz}$ & $\mathrm{D}_{1}$ & $7.1 \pm 2.3$ & $599 \pm 70$ & $7.2 \pm 2$ & $630 \pm 50$ \\
\hline Col de la mine de Fer & $13 \mathrm{~b}$ & $\mathrm{Grt} 1+\mathrm{St} 1+\mathrm{Bt} 1+\mathrm{Mus}+\mathrm{Plg}+\mathrm{Qtz}+\mathrm{Ru}$ & $\mathrm{D}_{1}$ & $8.8 \pm 1.2$ & $631 \pm 27$ & & $610 \pm 10$ \\
\hline $\begin{array}{l}\text { 'Micaschistes des } \\
\text { Roberts' }\end{array}$ & $13 \mathrm{c}$ & $\mathrm{Grt} 2+\mathrm{St} 2+\mathrm{Bt}+\mathrm{Mus}+\mathrm{Qtz}$ & $\mathrm{D}_{2}$ & $5 \pm 1$ & $520 \pm 40$ & & \\
\hline
\end{tabular}




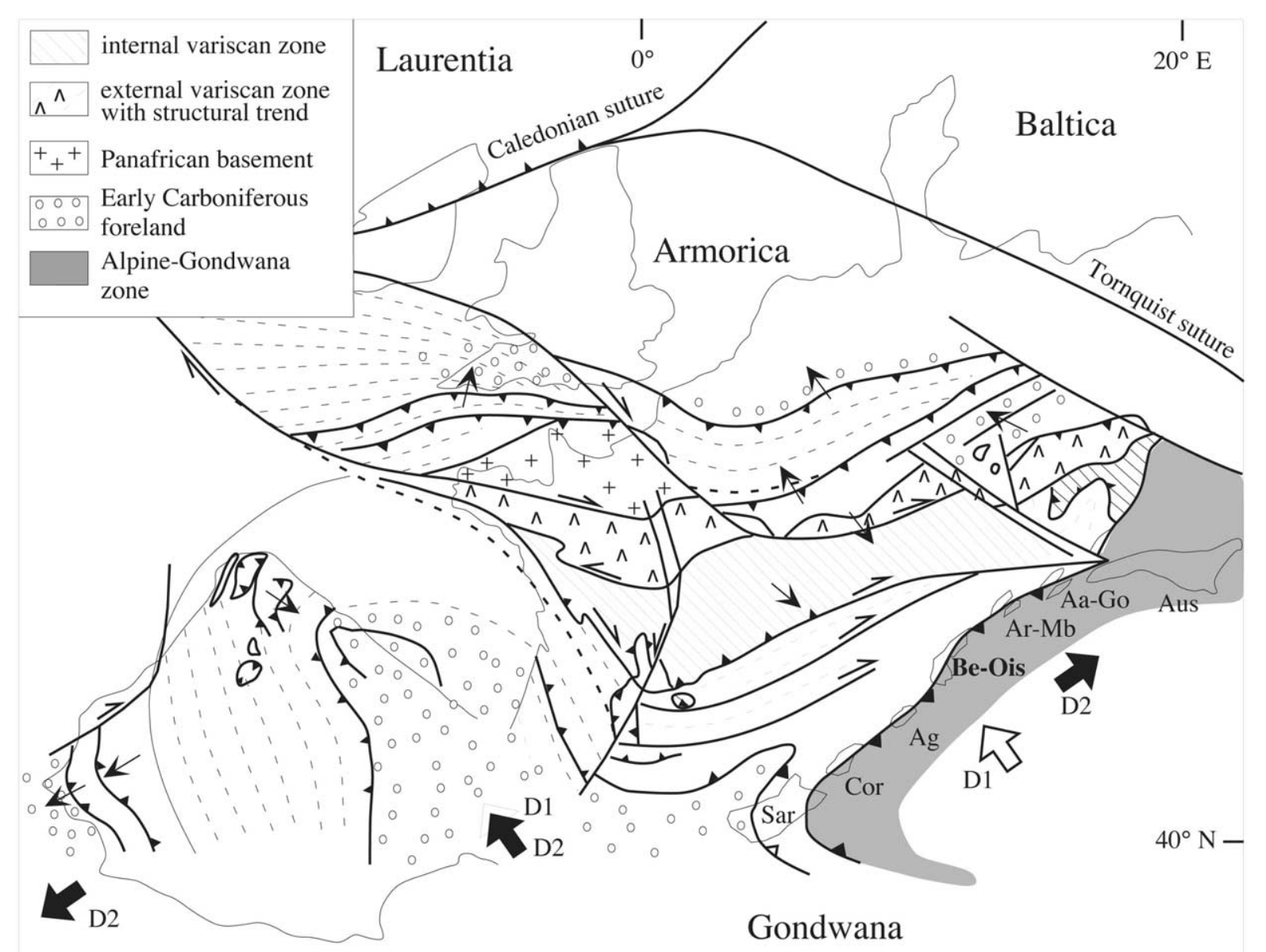

Fig. 14. Sketch map of the Early Carboniferous evolution of the Western European Hercynian belt with the D1 and D2 directions of shortening in the Belledonne massif and in the Ibero-Armorican arc. Notice that D1 and D2 directions of compression in the Ibero-Armorican arc are similar whereas in the Belledonne massif and in the southern part of the Ibererian block, D1 and D2 are roughly perpendicular suggesting a progressive lateral escape towards the SW and NE, respectively (modified after [5,31,33,39-41]). Sar, Sardinia; Cor, Corsica; Ag, Argentera; Be-Ois, Belledonne-Oisans; Ar-Mb, Aiguilles-Rouges Mont-Blanc; Aa-Go, Aar Gothard; Aus, Austro-Alpine domain.

matic indicators indicate the collapse of the southwestern parts and the unroofing of the northeast parts of the studied area. The $P-T$ conditions related to this early extensional event occurred in low-pressure anatectic conditions (4-6 kbar, $600-700{ }^{\circ} \mathrm{C}$ ) at the base of the nappe pile and in greenschist conditions at the ductile/brittle transition at the top of the nappe pile. The age of this event is clearly post-Visean, as it affects the Taillefer unit, and it seems to control the emplacement of the Westphalian basins. It is noticeable that a Namuro-Westphalian syn-convergent extension is well developed at the scale of the western European Paleozoic belt $[29,33,34]$. This extension is roughly parallel to the general strike of the orogen, i.e., along a northwest-southeast direction. In the Belledonne massif, this first phase of extension is also parallel to the local strike of the external crystalline massif, i.e., along a southwest-northeast direction (Fig. 15). This direction is perpendicular to the global direction of Europe-Africa convergence [35]. This suggests that, as for the D2 event, the Belledonne massif was still located on the northeastern side of the Ibero-Armorican arc and recorded a syn- extensional tectonic, perpendicular to the direction of convergence as presently observed in South Tibet [36] as already proposed in $[33,37]$.

The second extensional event D4 is characterized by an ductile/brittle extensional fault oriented northeast-southwest and has been only recognized in the upper and intermediate levels of the nappe pile. The kinematic analysis shows a northwest-southeast direction of extension. The bedding of the Stephanian deposits in the half-graben sedimentary basins of 'La Grande Lauzière' is oriented $\mathrm{N} 45^{\circ} 25^{\circ} \mathrm{NW}$, i.e., parallel to the direction of the main normal faults. This sedimentary basin is also delimited by conjugated extensional fault dipping towards the SE, and suggesting that the NW-SE post-thickening extension also controlled the opening of this Stephanian basin. As for the early extensional event, the Stephanian extension in the southwest Belledonne massif is roughly perpendicular to the direction of extension observed in the French Massif Central [34] but remains perpendicular to the strike of the Belledonne massif (Fig. 15). 


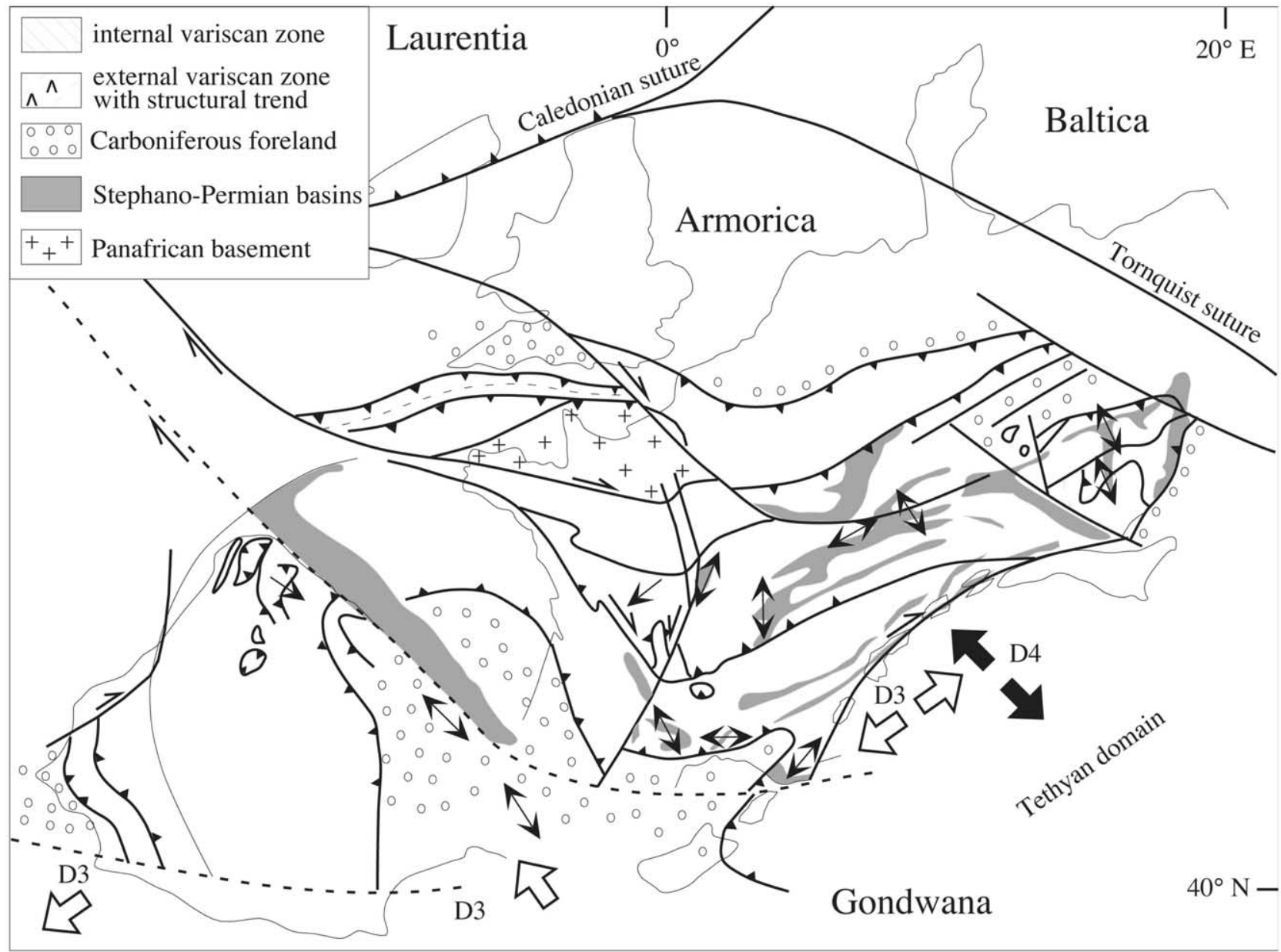

Fig. 15. Sketch map of the Late Carboniferous evolution of the European Hercynian belt with the D3 and D4 directions of extension in the Belledonne massif. Notice that the D4 direction of extension is perpendicular to the global orientation of the Stephano-Permian basins from the eastern part of the French Massif Central to the Bohemian Massif (modified after [5,31,33,39-42]).

\section{Conclusion}

A structural and metamorphic analysis on the southwestern area of the Belledonne massif (external crystalline massifs) demonstrates that this massif belongs to the external part of the Hercynian belt. We propose that the successive compressional and extensional events developed in the SW Belledonne domain from Late Devonian to Westphalian time correspond to the progressive northwestward indenta tion of the Hercynian belt, on the northeastern side of the Ibero-Armorican arc. In contrast, the Stephanian extensional tectonics records in the SW Belledonne domain corresponds to a probable change in the plate motions leading to the orogenic collapse towards the SE.

\section{Acknowledgements}

We wish to thank Michel Faure, Véronique Gardien, Jean-Marc Lardeaux for stimulating discussions and Guido Schreurs for English corrections. Suggestions by two anonymous reviewers improved the quality of the manu- script. This work was supported by the CNRS-BRGM-MRT program 'Geo-France 3D-Alpes' GeoFrance 3D contribution No. 121.

\section{References}

[1] J.F. von Raumer, The External Massifs, relics of Variscan basement in the Alps, Geol. Rund. 73 (1984) 1-31.

[2] J.F. von Raumer, R.P. Ménot, J. Abrecht, G. Biino, The Pre-Alpine evolution of the External massifs, in: J. von Raumer, F. Neubauer (Eds.), The Pre-Mesozoic Geology in the Alps, Springer, Berlin, Heidelberg, New York, 1993, pp. 221-240.

[3] R.P. Ménot, Magmatisme Paléozoïque et structuration carbonifère du massif de Belledonne (Alpes Françaises), Contraintes nouvelles pour les schémas d'évolution de la châne varisque OuestEuropéenne, Mém. Doc. CAESS Rennes, 1988, pp. 465.

[4] G. Stampfli, The intra-Alpine terrain: a palaeotethyan remnant in the Alpine Varisides, Eclo. Geol. Helve. 89 (1996) 12-42.

[5] J.F. von Raumer, The Palaeozoic evolution in the Alps: from Gondwana to Pangea, Geologische Rundschau 87 (1998) 407-435.

[6] F. Carme, Précisions nouvelles sur l'ampleur et le style de la tectonique tangentielle hercynienne dans la chaîne de Belledonne, $\mathrm{C}$. R. Acad. Sci. Paris 277 (1973) 2309-2312. 
[7] R.P. Ménot, An overview of the geology of the Belledonne massif (external crystalline massifs of Western Alps, Sweiz. Mineral. Petrogr. Mitt. 70 (1988) 33-53.

[8] S. Guillot, R.P. Ménot, Nappe stacking and first evidence of late variscan extension in the Belledonne Massif (External Crystallines Massifs, French Alps), Geodinam. Acta 12 (1999) 97-111.

[9] R.P. Ménot, M. Bonhomme, G. Vivier, Structuration tectonométamorphique carbonifère dans le massif de Belledonne (Alpes occidentales françaises). Apport de la géochronologie $\mathrm{K} / \mathrm{Ar}$ des amphiboles, Sweiz. Minéral. Petrogr. Mitt. 67 (1987) 273-284.

[10] C. Aubourg, C. Chabert-Pelline, Neogene remagnetization of normal polarity in the Late Jurassic black shales from the southern Subalpine Chains (French Alps). Evidence for late anticlockwise rotations, Tectonophysics 308 (1999) 473-486.

[11] S. Guillot, R.P. Ménot, A. Fernandez, Paleozoic evolution of the External Crystalline Massifs along the Belledonnne-Oisans transect (Western Alps), Acta Univ. Carol. 42 (1998) 257-259.

[12] F. Carme, Notice de la carte géologique de Vizille, vol. 35, 1972, pp. 35.

[13] M. Faure, X. Charonnat, A. Chauvet, Schéma structural et évolution tectonique du domaine para-autochtone cévenol de la chaîne hercynienne (Massif Central Français), C. R. Acad. Sci. 328 (1999) 401-407.

[14] F. Debon, M. Lemmet, Evolution of $\mathrm{Mg} / \mathrm{Fe}$ ratios in Late Variscan plutonic rocks from the External Crystalline Massifs of the Alps (France, Italy, Switzerland), J. Petrol. 40 (1999) 1151-1185.

[15] R.P. Ménot, J.L. Paquette, Geodynamics Significance of Basic and Bimodal Magmatism in the External Domain, Springer, New York, 1994, pp. 131-147.

[16] R.P. Ménot, J.J. Peucat, D. Scarenzi, M. Piboule, 496 Ma age of plagiogranites in the Chamrousse ophiolite complex (External Crystalline massifs in the French Alps): evidence of a Early Paleozoic oceanization, Earth Planet. Sci. Lett. 88 (1988) 82-92.

[17] C. Pin, F. Carme, A Sm-Nd isotopic study of a 500 Ma old oceanic crust in the Variscan belt of Europe: the Chamrousse ophiolite complex, Western Alps (France), Contrib. Mineral. Petrol. 96 (1987) $125-138$.

[18] J.L. Bodinier, C. Dupuy, J. Dostal, F. Carme, Geochemistry of ophiolites from the Chamrousse complex (Belledonne massif, Alps), Contrib. Mineral. Petrol. 78 (1981) 379-388.

[19] S. Guillot, R.P. Ménot, J.M. Lardeaux, Tectonique intra-océanique distensive dans l'ophiolite paléozoïque de Chamrousse (Alpes occidentales), Bull. Soc. Géol. France 163 (1992) 229-240.

[20] J.C. Barfety, M. Gidon, R.P. Ménot, F. Debon, S. Pêcher, S. Guillot, J.C. Fourneaux, J.F. Gamond, Notice feuille de Domène, 1/50,000 773 (2000)

[21] J. Ramsay, R.H. Graham, Strain variation in shear belts, Can. J. Earth Sci. 7 (1970) 786-813.

[22] J.M. Ferry, F.S. Spear, Experimental calibration of the partitioning of $\mathrm{Fe}$ and $\mathrm{Mg}$ between biotite and garnet, Contrib. Mineral. Petrol. 66 (1978) 113-117.

[23] I.V. Lavent'eva, L.L. Perchuk, Experimental investigation of exchange equilibria in the system cordierite-garnet-biotite, in: S.K. Saxena (Ed.), Kinetics and Equilibrium in Mineral Reactions, Springer, 1981, pp. 199-240.

[24] L.L. Perchuk, The staurolite-garnet thermometer, Dokl. Acad. Sci. USSR 186 (1989) 189-191.

[25] T.D. Hoisch, Empirical calibration of six geothermobarometer for the mineral assemblage quartz + muscovite + biotite + plagioclase + garnet, Contrib. Mineral. Petrol. 104 (1990) 225-234.
[26] R. Powell, T.J.B. Holland, An internally consistent thermodynamic dataset with uncertainties and correlation: applications to geobarometry, worked examples and a computer program, J. Metamorphic Geol. 24 (1988) 173-204.

[27] V. Gardien, J.M. Lardeaux, P. Ledru, P. Allemand, S. Guillot, Metamorphism during late orogenic extension: insights from the French Variscan belt, Bull. Soc. Geol. Fr. 168 (1997) 271-286.

[28] P. Ledru, S. Costa, H. Echtler, The Massif Central, Structure, in: J.D. Keppie (Ed.), Pre-Mesozoic Geology in France and Related Areas, Springer, 1994, pp. 305-323.

[29] M. Faure, C. Leloix, J.Y. Roig, L'évolution polycyclique de la chaîne hercynienne, Bull. Soc. Géol. Fr. 168 (1997) 695-705.

[30] C. Leloix, M. Faure, J.L. Feybesse, Hercynian polyphase tectonics in the northeast French Massif Central: the closure of the Brévenne Devonian-Dinantian rift, Int. J. Earth Sci. 88 (1999) 409-421.

[31] P. Matte, La chaîne varisque parmis les chaînes paléozoïques péri-atlantique, modèle d'évolution et position des grands blocs continentaux au Permo-Carbonifère, Bull. Soc. Géol. Fr. 8 (1986) $4-24$.

[32] P. Tapponnier, G. Peltzer, R. Armijo, On the mechanics of the collision between India and Asia, in: Coward, A.C. Riess (Eds.), Collision Tectonics, Geological Society of London Special Publication 19 (1986) 115-157.

[33] J.P. Burg, J. Van den Driessche, J.P. Brun, L'extension syn- à post épaississement de la chaîne Varisque en Europe Occidentale: modalités et conséquences, Géol. Fr. 3 (1994) 33-51.

[34] M. Faure, Late orogenic carboniferous extensions in the Variscan French Massif Central, Tectonics 14 (1995) 132-153.

[35] R. Van der Voo, Pre-Mesozoic paleomagnetism and plate tectonics, Ann. Rev. Earth Planet. Sci. 10 (1982) 191-220.

[36] R. Armijo, P. Tapponnier, J.L. Mercier, T.L. Han, Quaternary extension in Southern Tibet: field and tectonic implications, J. Geophys. Res. 91 (1986) 13803-13872.

[37] J.F. Beck-Giraudon, J. Van den Driessche, Dépots péri-glaciaires dans le Stéphano-Autunien du Massif Central: témoin de l'éffondrement gravitaire d'un haut plateau hercynien, C. R. Acad. Sci. 318 (1993) 675-682.

[38] G. Vivier, R.P. Ménot, P. Giraud, Magmatismes et structuration orogénique paléozoïque de la chaîne de Belledonne (massifs cristallins externes alpins), Le domaine nord-oriental 63 (1987) $25-53$.

[39] P. Matte, Continental subduction and exhumation of HP rocks in paleozoic orogenic belts: Uralides and Variscides, GFF 120 (1998) 209-222.

[40] P. Matte, The Variscan collage and orogeny (480-290 Ma) and the tectonic definition of the Armorica microplate: a review, Terra Nova 13 (2001) 122-128.

[41] J.P. Bard, Démembrement anté-Mésozoïque de la chaîne hercynienne d'Europe Occidentale du Nord: rôle essentiel des grands décrochements tanspressifs dextres accompagnant la rotationtranslation horaire de l'Afrique durant le Stéphanien, C. R. Acad. Sci. 324 (1997) 693-704.

[42] G. Ménard, P. Molnard, Collapse of a Hercynian Tibetan Plateau into a late Palaeozoic European Basin and Range province, Nature 334 (1988) 235-237. 